\title{
МИКРОБИОТА КИШЕЧНИКА И ПРОДУКТИВНЫЕ КАЧЕСТВА БРОЙЛЕРОВ ПРИ ИСПОЛЬЗОВАНИИ ФИТАЗЫ ДЛЯ ПОВЫШЕНИЯ УСВОЯЕМОСТИ ФОСФОРА И ПИТАТЕЛЬНЫХ ВЕЩЕСТВ ИЗ КОМБИКОРМОВ
}

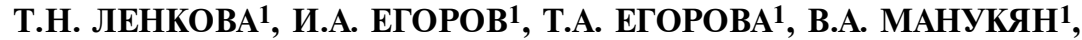 \\ В.Г. ВЕРТИПРАХОВ 1 , А.А. ГРОЗИНА', И.Н. НИКОНОВ 1 , В.А. ФИЛИППОВА ${ }^{2}$, \\ Е.А. ЙЫЛДЫРЫМ 2 , Л.А. ИЛЬИНА², А.В. ДУБРОВИН ${ }^{2}$, Г.Ю. ЛАПТЕВ 2
}

Фосфор - жизненно необходимый элемент в питании человека, животных и растений. Для цыплят-бройлеров (Gallus gallus L.) проблема минерального питания и баланса минеральных веществ (включая кальций и фосфор) особенно актуальна из-за короткого периода роста (34-42 сут) при быстром увеличении живой массы и формировании скелета. В растительных ингредиентах кормов фосфор находится в виде фитатных соединений, которые практически не усваиваются организмом птицы. По этой причине в рационы сельскохозяйственной птицы вводят фитазы - ферментные препараты, расщепляющие неусвояемые фитатсодержащие комплексы. Данные российских (О.В. Труфанов, 2011; Е.В. Анчиков, 2012) и зарубежных авторов (S.W. Kim et al., 2018; C.L. Walk et al., 2019; O.O. Babatunde et al., 2019) свидетельствуют о том, что при уменьшенном содержании фосфора в рационе фитаза положительно влияет на суточную прибавку в живой массе, содержание фосфора в крови, прочность большеберцовой кости и содержание минеральных веществ в большеберцовой кости. Нашей целью было изучение влияния двух фитазосодержащих препаратов отечественного производства на продуктивность, минерализацию костяка, переваримость и использование питательных веществ корма бройлерами, а также оценка влияния концентрированной формы препарата на состав микробиома слепых отростков кишечника. Научно-производственные опыты на бройлерах (Gallus gallus L.) кросса Cobb 500 проводили в 2018 году в виварии Селекционно-генетического центра «Загорское ЭПХ» (г. Сергиев Посад, Московская обл.). Опыт 1 выполняли на птице с 1-суточного до 37-суточного возраста, опыт 2 - с 1-суточного до 36-суточного возраста. В каждом опыте методом аналогов по живой массе были сформированы четыре группы цыплят: I - контрольная, II-IV - опытные (по 35 гол. в группе). В контрольных группах корма были выравнены по содержанию питательных веществ, в опытных количество усвояемого фосфора снижали на 0,1 \%. Энзим вводили в комбикорма методом ступенчатого смешивания. В опыте 1 препарат Фидбест-Р (10000 ед/г; ООО ПО «Сиббиофарм», г. Бердск, Россия) включали в комбикорма в количестве 20 г/т (II группа), 40 г/т (III группа) и 60 г/т (IV группа). В опыте 2 препарат Берзайм-P (50000 ед/г; ОOО ПО «Сиббиофарм", г. Бердск, Россия) использовали в количестве 6 г/т (II группа), 12 г/т (III группа) и 30 г/т (IV группа). Учитывали сохранность поголовья, живую массу в 1-, 7-, 14-, 21- и 36-37суточном возрасте, а также конверсию корма и среднесуточный прирост живой массы. В возрасте 28-36 сут проводили физиологические балансовые опыты, в которых определяли переваримость протеина, жира, клетчатки корма, баланс азота, кальция, фосфора. В конце выращивания определяли химический состав берцовой кости, химический состав грудных и ножных мышц. После убоя осуществляли анатомическую разделку тушек с определением убойного выхода потрошеной тушки. Пробы содержимого слепых отростков кишечника для анализа микрофлоры отбирали у цыплят после убоя в 36-суточном возрасте. Для изучения состава микрофлоры использовали метод T-RFLP (terminal restriction fragment length polymorphism). Использование препарата Фидбест-Р позволило повысить живую массу 37-суточных цыплят во II, III и IV опытных группах соответственно на 2,7; 3,0 и 3,7 \% и улучшить конверсию корма на 2,9; 4,0 и 4,6 \% по сравнению с контролем. Обогащение комбикормов препаратом Берзайм-Р способствовало улучшению аналогичных показателей на 1,$3 ; 3,1$ и 2,0 \% и 1,9; 5,6 и 3,7 \%. В обоих опытах было установлено положительное влияние энзима на переваримость питательных веществ рациона, усвоение кальция и фосфора, минерализацию костяка цыплят. У цыплят, получавших Берзайм-Р, изучение микрофлоры слепых отростков кишечника показало значительный рост пула целлюлозолитических бактерий, а также бактерий, принадлежащих к семействам Eubacteriaceae, Clostridiaceae, Lachnospiraceae, Ruminococcaceae и филуму Bacteroidetes. Большинство идентифицированных бактерий были отнесены к филумам Firmicutes, Bacteroidetes, Actinobacteria, Proteobacteria

\footnotetext{
* Исследование выполнено при поддержке гранта РНФ для реализации научного проекта 16-16-04089 «Изучение физиологических и микробиологических особенностей пищеварения кур мясных пород в эмбриональный и постэмбриональный периоды для создания новых технологий кормления, обеспечивающих максимально полную реализацию генетического потенциала птицы». 
Ключевые слова: Gallus gallus, фитаза, комбикорма, бройлеры, продуктивность, микрофлора кишечника.

Ферментные препараты обладают высоким потенциалом практического использования в кормопроизводстве. В последнее время ассортимент комбикормов для птицы почти на 90 \% обогащают фитазами - ферментными препаратами, расщепляющими неусвояемые фитатсодержащие комплексы. Применение таких ферментов обусловлено необходимостью воздействовать на фитатный фосфор растительных ингредиентов кормов, снижать содержание неорганических фосфатов в рационах, а также уменьшать экскрецию фосфора с пометом в окружающую среду (1-3). Особенно остро нуждается в фосфоре молодняк птицы, в частности цыплятабройлеры. Селекция мясной птицы по скорости роста привела к тому, что развитие костяка отстает от формирования мышечной ткани. В связи с этим у цыплят часто отмечаются аномалии ног незаразной этиологии (4).

Рынок фитазных препаратов для животноводства достаточно разнообразен, насыщен и представлен фитазами бактериального и грибного происхождения. Для потребителя прежде всего важна активность фитазы, от которой зависит ее доза при добавлении к комбикорму, а также стоимость препарата, термостабильность, эффективность применения на птице (5). Ввод фитазосодержащих энзимов в корма осуществляется как посредством премиксов, так и при обогащении комбикормов непосредственно в хозяйствах. В связи с этим важно учитывать возможность оборудования для однородного размешивания препаратов или включения их в комбикорма через премиксы.

Введение фитазы в рацион животных и птицы может влиять на физические и химические свойства химуса в желудочно-кишечном тракте, прежде всего на $\mathrm{pH}$, что приводит к сдвигам профилей кишечной микробиоты и активности ее представителей. Максимальную активность фитаза проявляет в кислой среде при рН от 3 до 6, то есть фитатный фосфор начинает высвобождаться уже в зобе птиц и мускульном желудке (6). Введение фитазы в рацион бройлеров в разных дозировках (от 0 до 12000 ед/кг живой массы) при снижении количества кальция и фосфора способствовало значительному увеличению среднесуточного прироста массы цыплят, содержания фосфора в сыворотке крови, прочности и содержания золы в большеберцовой кости (7). Однако, несмотря на положительные качества, фитаза может оказывать и отрицательное воздействие на усвоение лизина, цистеина, аспарагиновой кислоты, глицина, метионина, триптофана, серина (8). Независимо от типа продуктивности птицы, ее возраста и рациона, фитаза во всех случаях увеличивает доступность фитинового фосфора и его количество в содержимом тощей кишки. Она действует эффективнее в период интенсивного роста цыплят (14-22-е сут), когда происходит активный рост и формирование костной ткани (9). Также на эффективность действия фитазы в рационе птиц влияет размер частиц минеральной составляющей рациона (10). При совместном использовании фитазы с ксиланазой или $\beta$-глюканазой в рационе цыплят-бройлеров наблюдалось снижение потребления корма, а также колонизации кишечника Escherichia coli (11), однако изменений в органах пищеварительной системы выявлено не было.

Известно, что микробиоценоз кишечника птицы представляет собой достаточно богатое и сложное по структуре сообщество видов симбиотических микроорганизмов, состоящее из бактерий, архей, микромицетов, 
простейших и вирусов (12-15). Основные обитатели микробиома кишечника кур - бактерии (16). Появление методики секвенирования генов 16S рРНК позволило выявить в составе микробиоэкосистемы кишечника кур представителей 13 бактериальных филумов, из которых доминирующими (>90 \%) оказались Firmicutes, Bacteroidetes и Proteobacteria. В целом в кишечнике кур было обнаружено более 900 эквивалентов операционным таксономическим единицам (ОТЕ), 117 из которых принадлежали к известным бактериальным родам. При этом данные о влиянии включения в корма фитазы на микробную экосистему желудочно-кишечного тракта крайне ограничены.

В представленной работе изменение состава микрофлоры слепых отростков кишечника у цыплят-бройлеров при добавлении к кормам препаратов фитазы с разной активностью впервые изучили методом T-RFLP (terminal restriction fragment length polymorphism), обладающим рядом преимуществ по сравнению с классическими методами бактериологии. Показано, что в результате применения российских препаратов Фидбест-Р и Берзайм-Р представители нормофлоры в основном получают конкурентное преимущество, а численность условно-патогенных и патогенных форм в микробном сообществе падает. Препараты позволяют использовать комбикорм с пониженным содержанием усвояемого фосфора, улучшают переваримость протеина, жира, утилизацию азота, аминокислот, кальция, фосфора и микроэлементов (железо, марганец, медь, цинк).

Нашей целью было изучение влияния двух фитазосодержащих препаратов отечественного производства на продуктивность, минерализацию костяка, переваримость и использование питательных веществ корма бройлерами, а также оценка влияния концентрированной формы препарата на состав микробиома слепых отростков кишечника.

Методика. Научно-производственные опыты проводили на бройлерах (Gallus gallus L.) кросcа Cobb 500 (виварий Селекционно-генетического центра «Загорское ЭПХ», г. Сергиев Посад, Московская обл., 2018 год). Первый опыт (опыт 1) выполняли на птице с 1-суточного до 37суточного возраста, второй (опыт 2) - с 1-суточного до 36-суточного во3раста. Для каждого опыта методом аналогов по живой массе сформировано по четыре группы цыплят: I - контрольная, II-IV - опытные (всего 280 гол., по 35 гол. в группе). Цыплят содержали в клеточных батареях AviMax («Big Dutchman», Германия) с соблюдением всех технологических параметров (17).

Первые 5 сут цыплята всех групп получали одинаковые престартерные комбикорма. Далее (с 6-х по 21-е сут и с 22-х сут до конца выращивания) питательность комбикормов соответствовала возрастным нормам для кросса. В контрольных группах корма были выравнены по содержанию питательных веществ, в опытных - количество усвояемого фосфора снижали на $0,1 \%$. Энзим вводили в комбикорма методом ступенчатого смешивания. В опыте 1 препарат Фидбест-Р (ООО ПО «Сиббиофарм», г. Бердск, Россия) включали в комбикорма в количестве 20 г/т (II группа), 40 г/т (III группа) и 60 г/т (IV группа). В опыте 2 препарат Берзайм-P (ООО ПО «Сиббиофарм», г. Бердск, Россия) использовали в количестве 6 г/т (II группа), 12 г/т (III группа) и 30 г/т (IV группа). В первом препарате активность фермента стандартная (10000 ед/г), во втором (концентрированном) - 5-кратная (50000 ед/г).

Учитывали сохранность поголовья, живую массу в 1-, 7-, 14-, 21- и 36-37-суточном возрасте (начиная с 21-х сут курочек и петушков взвеши- 
вая раздельно), а также конверсию корма и среднесуточный прирост живой массы. В возрасте 28-36 сут проводили физиологические балансовые опыты, в которых определяли переваримость протеина, жира, клетчатки корма, баланс азота, кальция, фосфора. Для этого в клетку сажали по 3 птицы (аналоги по живой массе) из каждой группы, учитывали количество потребленного корма и выделенного помета, а также проводили их химический анализ. В конце выращивания определяли химический состав берцовой кости, химический состав грудных и ножных мышц. После убоя осуществляли анатомическую разделку тушек и определяли убойный выход потрошеной тушки (18).

Образцы содержимого слепых отростков кишечника для анализа микрофлоры отбирали у цыплят после убоя в 36-суточном возрасте (по три повторности из каждой группы) со строгим соблюдением правил асептики и методики отбора проб (18) и немедленно замораживали.

Для изучения состава микрофлоры использовали метод T-RFLP (terminal restriction fragment length polymorphism). Тотальную ДНК из образцов выделяли с помощью набора DNA Purification Kit («Fermentas, Inc.», Литва), следуя рекомендациям производителя. ПЦР (ДНК-амплификатор Verity, «Life Technologies, Inc.», США) проводили с эубактериальными праймерами 63F 5'-CAGGCCTAACACATGCAAGTC-3' с меткой на 5'-конце (флуорофор D4 WellRED, «Sigma-Aldrich, Inc.», США) и 1492R 5'-TACGGHTACCTTGTTACGACTT-3', которые позволяют амплифицировать фрагмент гена 16S pРНК (позиции от 63-й до 1492-й; нумерация указана для гена $16 \mathrm{~S}$ рРНК Esherichia coli) в следующем режиме: 3 мин при $95{ }^{\circ} \mathrm{C}$ (1 цикл); 30 с при $95{ }^{\circ} \mathrm{C}, 40$ с при $55^{\circ} \mathrm{C}, 60$ с при $72{ }^{\circ} \mathrm{C}$ (35 циклов), 5 мин при $72{ }^{\circ} \mathrm{C}$ Флуоресцентно меченные ампликоны ДНК гена $16 \mathrm{~S}$ pРНК очищали по стандартной методике (19). Концентрацию очищенных фрагментов определяли с помощью флуориметра Qubit 2.0 («Invitrogen», Германия) согласно рекомендации изготовителя. Для рестрикции (30-50 нг ампликонов) использовали ферменты HaeIII, HhaI и MspI («Fermentas», Литва). Продукты рестрикции секвенировавли (CEQ 8000, «Beckman Coulter», США). Для определения филогенетической принадлежности бактерий использовали программу Fragment Sorter и базу данных (http://www.oardc.ohiostate.edu/trflpfragsort/index.php).

Математическую и статистическую обработку результатов проводили стандартными методами дисперсионного анализа (20) с использованием программного обеспечения Microsoft Excel 2010. Применяли параметрические ( $t$-критерий Стьюдента) и непараметрические (метод Вилкоксона-Манна-Уитни) методы статистики. Определяли средние значения $(M)$ и стандартные ошибки средних $( \pm \mathrm{SEM})$. Биологическое разнообразие оценивали с помощью индексов Шеннона и Симпсона в программе Past (http://folk.uio.no/ohammer/past/). Для объяснения причинно-следственной связи между содержанием микроорганизмов в слепых отростках кишечника и использованием фосфора организмом птицы рассчитывали коэффициенты корреляции Пирсона, позволяющие установить прямые связи между переменными величинами по их абсолютным значениям (20). Показатели корреляции анализировали в тех случаях, когда содержание определенного микроорганизма в общем микробном сообществе превышало $1 \%$.

Результаты. Включение в рационы цыплят-бройлеров отечественных фитазосодержащих препаратов привело к повышению усвоения фитинового фосфора, увеличению переваримости и использования других питательных веществ рациона. Так, в опыте 1 введение в комбикорм пре- 
парата Фидбест-Р способствовало повышению использования фосфора на 4,2 \% во II группе, на 6,6 \% - в III группе и на 7,1 \% - в IV группе по отношению к контролю (рис. 1, А). При этом переваримость сухого вещества корма во II, III и IV опытных группах оказалась выше, чем в контрольной, соответственно на 1,2; 2,8 и 3,0 \%, жира - на 3,0; 3,7 и 3,9\%.

Установлено, что фитаты связывают положительно заряженные ионы металлов - макро- и микроэлементов (ионы кальция, цинка, железа, марганца, магния), а также белки, аминокислоты, крахмал, снижая их биодоступность (9). Результаты опыта 1 показали, что применение фитазы способствовало улучшению использования кальция корма во II, III и IV группах цыплят соответственно на 1,8; 3,0 и 3,5 \%. Добавка фитазы привела к улучшению усвояемости протеина животного происхождения (при его достаточно низком количестве в рационе). Переваримость протеина во II, III и IV группах была выше контроля на 1,2; 1,4 и 1,5\%. Азот корма бройлеры опытных групп также использовали лучше (на 2,2-2,8 \%), чем в контроле. Усвояемость незаменимых аминокислот (лизина и метионина) была выше в опытных группах в среднем на 3,0-3,5 и 3,1-4,0 \%.

A

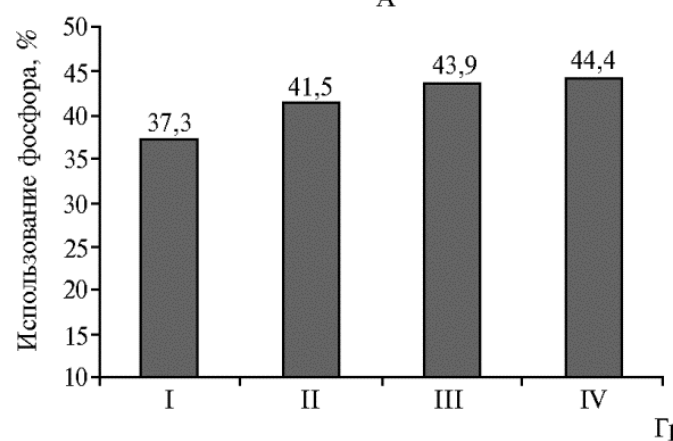

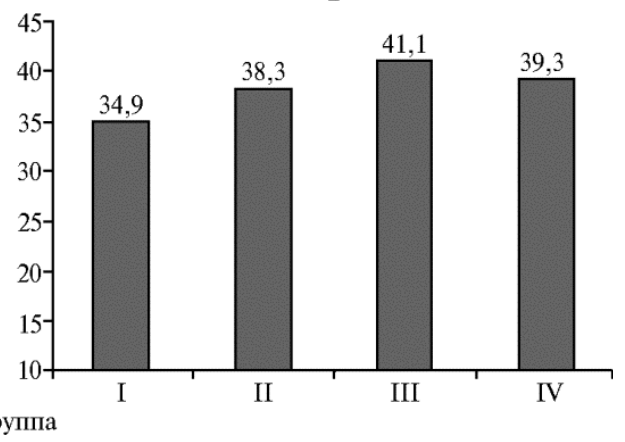

Рис. 1. Усвоение фосфора бройлерами (Gallus gallus L.) кросса Cobb 500 при добавлении в рацион препаратов Фидбест-Р (А) и Берзайм-Р (Б) в разных дозах. Описание рационов для групп см. в разделе «Методика» (по $n=35$ в группе; виварий Селекционно-генетического центра «Загорское ЭПХ», г. Сергиев Посад, Московская обл., 2018 год).

Поскольку под влиянием фитазы улучшилось усвоение организмом бройлеров фосфора и кальция, была выявлена тенденция к увеличению количества этих микроэлементов в большеберцовых костях. Кроме того, у цыплят всех опытных групп отмечалось более высокое по сравнению с контролем содержание в костях железа (на 2,54-2,91 мг\%), марганца (на 0,05-0,13 мг\%), меди (на 0,06-0,013 мг\%), цинка (на 0,45-1,16 мг\%).

Благодаря повышению переваримости и использования питательных веществ корма живая масса у 37-суточных бройлеров оказалась выше во II, III и IV группах соответственно на 2,7; 3,0 и 3,7 \% по сравнению с контрольными цыплятами (I группа), в том числе у курочек - на 1,6; 2,1 и $2,5 \%$, у петушков - на 3,6; 3,9 и 4,8 \%. Конверсия корма в указанных группах была лучше, чем в контроле, на 2,9; 4,0 и 4,6 \%.

Обогащение комбикорма препаратом Берзайм-Р в опыте 2 тоже положительное повлияло на организм бройлеров (см. рис. 1, Б). Так, во II, III и IV опытных группах использование фосфора оказалось выше, чем в контроле, соответственно на 3,4; 6,2 и 4,4 \%, кальция - на 1,5; 3,2 и 2,3 \%; переваримость сухого вещества корма повысилась на 0,8-2,6 \%, жира - на 1,1-3,2 \%. Переваримость протеина корма и использование азота в опыт- 
ных группах были выше на 0,9-2,9 и 1,3-2,8 \%.

Значительных различий в содержании сырой золы в большеберцовых костях у бройлеров из разных групп не наблюдалось. Была отмечена некоторая тенденция к увеличению кальция и фосфора в костяке у птицы из опытных групп. Как и в опыте 1, у бройлеров, получавших фитазу в составе корма, в большеберцовых костях содержание железа, марганца, меди и цинка было выше, чем в контроле. Живая масса 36-суточных бройлеров увеличилась во II, III и IV опытных группах соответственно на 1,$3 ; 3,1$ и 2,0 \% по отношению к контролю, причем у курочек оказалась выше на 1,$14 ; 3,0$ и 2,9 \%, у петушков - на 1,5; 3,3 и 1,3\%.

Важнейший критерий оценки мясных качеств бройлеров - убойный выход мяса потрошеной тушки. По результатам обоих опытов этот показатель был выше в опытных группах. Химический анализ грудных и ножных мышц бройлеров показал отсутствие существенных различий между опытными и контрольными группами по содержанию влаги, сырого протеина, жира, золы.

C применением метода T-RFLP в опыте 2 в составе микрофлоры

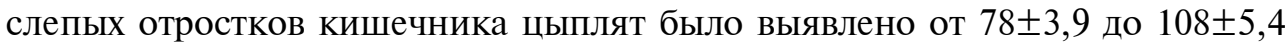
филотипов бактерий (табл.). Отмечено более выраженное таксономическое разнообразие и сложность организованности микробных сообществ кишечника в контрольной группе (без добавления фитазы), а также в III опытной группе (при введении в рацион препарата Берзайм-Р в дозе 12 г/т корма). Это указывает на неоднородность составов микробиоценоза, накопление энтропии и определенную степень дезорганизации в этих вариантах по сравнению со II и IV опытными группами.

Значения индексов биоразнообразия микроорганизмов в слепых отростках кишечника у бройлеров (Gallus gallus L.) кросса Cobb 500 при добавлении в рацион препарата Берзайм-Р в разных дозах (по $n=35$ в группе; $M \pm \mathrm{SEM}$, виварий Селекционно-генетического центра «Загорское ЭПХ», г. Сергиев Посад, Московская обл., 2018 год)

\begin{tabular}{l|c|c|c|c}
\hline \multicolumn{1}{c|}{ Показатель } & I группа & II группа & III группа & IV группа \\
\hline Количество филотипов & $101,0 \pm 4,60$ & $107,0 \pm 6,20$ & $78,0 \pm 3,90$ & $108,0 \pm 5,40$ \\
Индекс доминирования & $0,04 \pm 0,002$ & $0,33 \pm 0,018$ & $0,04 \pm 0,002$ & $0,31 \pm 0,014$ \\
Индекс Шеннона & $3,57 \pm 0,180$ & $1,46 \pm 0,062$ & $3,67 \pm 0,150$ & $1,64 \pm 0,050$ \\
Индекс Симпсона & $0,96 \pm 0,038$ & $0,67 \pm 0,020$ & $0,96 \pm 0,041$ & $0,69 \pm 0,047$ \\
Индекс Маргалефа & $21,2 \pm 1,50$ & $11,4 \pm 0,49$ & $16,7 \pm 0,72$ & $13,6 \pm 0,59$ \\
\multicolumn{2}{l}{ П р и м е ч а и е. Описание групп см. в разделе «Методика». } &
\end{tabular}

Значительную долю микроорганизмов, выявленных в слепых отростках кишечника бройлеров, не удалось отнести ни к одному существующему таксону (рис. 2). Так, количество неидентифицированных бактерий составляло от $4,7 \pm 0,3$ до $12,3 \pm 0,52 \%$ в зависимости от группы цыплят. Наибольшее количество таких микроорганизмов обнаружили в IV опытной группе. Высокую долю некультивируемых бактерий в составе микробиоты кишечника кур исследователи выявляли и ранее (21).

Качественный состав идентифицированных микроорганизмов кишечника бройлеров в целом был сходен во всех вариантах (см. рис. 2). В большинстве образцов бактерии были отнесены к филумам Firmicutes, Bacteroidetes, Actinobacteria, Proteobacteria и Fusobacteria. Доминирующими во всех вариантах оказались бактерии из филума Firmicutes. Наши данные частично согласуются с результатами, полученными ранее (22-24). Так, на основе результатов секвенирования гена $16 \mathrm{~S}$ рРНК было показано, что в микробных сообществах кишечника бройлеров преобладали представители филумов Firmicutes и Proteobacteria, на которые приходилось более 90 \% 


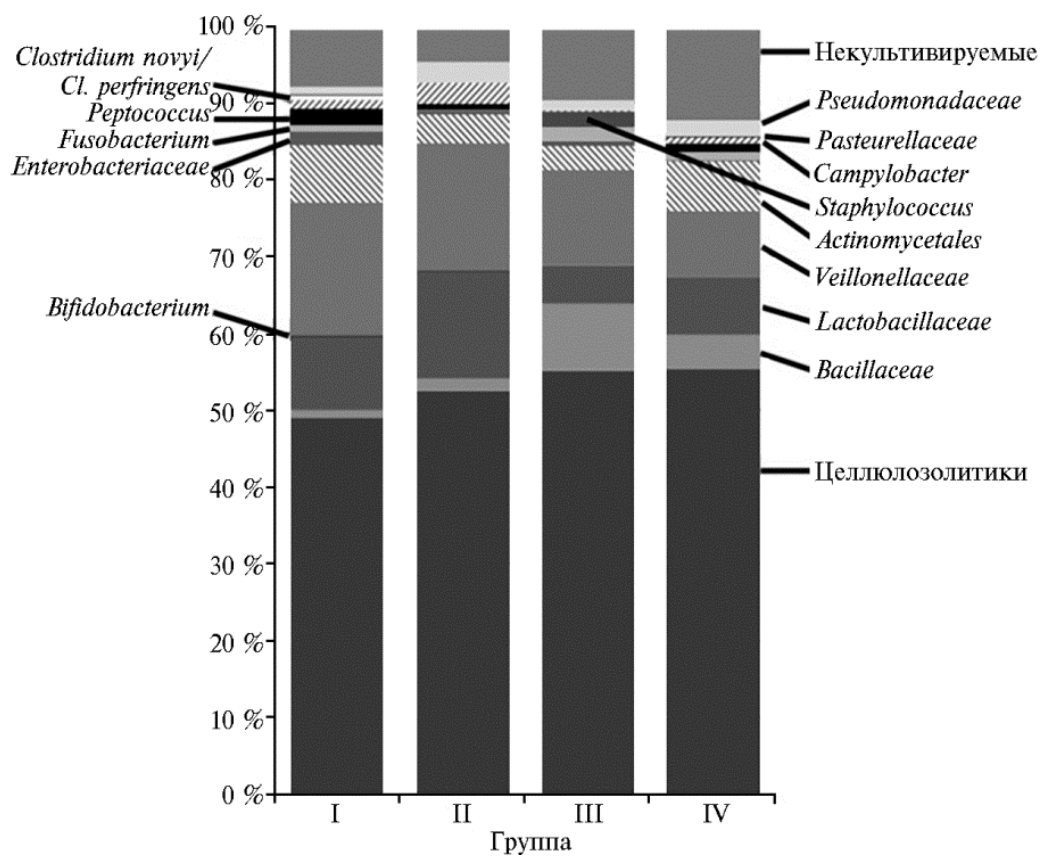

Рис. 2. Состав микробиоценоза слепых отростков кишечника у бройлеров (Gallus gallus L.) кросса Cobb 500 при разном содержании фитазы в рационе (результаты T-RFLP анализа). Описание групп см. в разделе «Методика».

Интересно, что добавление фитазы в рационы способствовало росту пула целлюлозолитических бактерий, принадлежащих к семействам Eubacteriaceae, Clostridiaceae, Lachnospiraceae, Ruminococcaceae и филуму Bacteroidetes. Эти микроорганизмы играют важную роль в пищеварении птиц, поскольку образуют ряд пищеварительных ферментов, в том числе целлюлаз, что позволяет макроорганизму эффективно использовать энергию кормов, богатых клетчаткой. Было отмечено снижение доли представителей порядка Actinomycetales в 1,2-2,3 раза и семейства Enterobacteriaceae в 2,8-14,4 раза в кишечнике бройлеров, получавших концентрированный препарат фитазы, по сравнению с контрольной группой. Среди представителей семейства Enterobacteriaceae встречаются патогенные виды родов Escherichia, Klebsiella, Enterobacter, Serratia, Citrobacter и др., поэтому снижение численности этой группы бактерий может указывать на коррекцию дисбиотических нарушений в кишечнике бройлеров.

Наибольшую долю бактерий семейства Lactobacillaceae $(13,8 \pm 0,62 \%)$ выявили в кишечнике цыплят из II опытной группы. Молочнокислые бактерии семейства Lactobacillaceae синтезируют в качестве основного продукта метаболизма лактат, снижающий значение $\mathrm{pH}$ химуса, что приводит к подавлению патогенных форм. Также по результатам эксперимента в слепых отростках кишечника цыплят II опытной группы отмечалась наименьшая доля представителей рода Fusobacterium sp., среди которых нередко встречаются возбудители воспалительных заболеваний. Помимо этого, количество бактерий группы Clostridium novyi/Cl. perfringens, представителей рода Staphylococcus и семейства Pasteurellaceae оказалось ниже предела достоверного определения методом T-RFLP. Тем не менее эти микроорганизмы были детектированы в кишечнике цыплят: стафилококки - в III $(1,88 \%)$ и IV $(0,19 \%)$ группах, клостридии - в контрольной $(0,73 \%)$, 
пастереллы - в контрольной $(0,09 \%)$ и IV $(0,23 \%)$ группах. Интересно, что среди бактерий рода Staphylococcus и семейства Pasteurellaceae нередко встречаются возбудители заболеваний кур, такие как Staphylococcus aureus и Pasteurella multocida. Бактерии видов Clostridium novyi и Cl. perfringens нередко ассоциируются с гастроэнтеритами и хромотой у кур $(26,27)$.

При сопоставлении состава микробиома кишечника и степени усвоения фосфора макроорганизмом результаты корреляционного анализа по Пирсону подтвердили наличие связи между функционально значимыми представителями микробного сообщества слепых отростков кишечника бройлеров и введением в рацион фитазы в разных дозировках. Так, повышение усвоения фосфора имело достоверную прямую связь с возрастанием количества целлюлозолитических бактерий $(r=0,98$ при $\mathrm{p} \leq 0,05)$, в частности увеличением численности представителей филума Bacteroidetes $(r=0,99$ при р $\leq 0,001)$ и семейства Lachnospiraceae $(r=0,84$ при р $\leq 0,05)$. При этом повышение доступности фосфора было связано со снижением количества бактерий семейств Veillonellaceae $(r=-0,84$ при $\mathrm{p} \leq 0,05)$ и Enterobacteriaceae $(r=-0,92$ при р $\leq 0,01)$.

Модулирующее влияние фитазы на состав микрофлоры может быть связано с повышением доступности фосфора, изменением $\mathrm{pH}$, а также других физико-химических показателей в просвете желудочно-кишечного тракта. Несмотря на то, что сведения об изменении микробных сообществ кишечника кур под влиянием фитазы крайне ограничены, результаты отдельных исследований указывают на то, что введение в рацион этого фермента способствует сдвигам в структуре микробиома. Так, A. Ptak и соавт. (25) показали увеличение численности групп Lactobacillus sp. и Enterococcus sp. под влиянием введения в рацион кур фитазы.

В литературе отмечают неодинаковую эффективность разных препаратов фитаз (28-31). Обобщая результаты своего эксперимента, мы можем констатировать, что оба отечественных фитазных препарата (Фидбест-Р и Берзайм-Р) при добавлении в комбикорма для бройлеров позволяют снизить дозу неорганического фосфора в рационе, повышая при этом продуктивность птицы. Как отмечают и другие авторы $(5,32)$, добавка в рационы фитаз позволяет увеличить среднесуточный прирост живой массы бройлеров и улучшить конверсию корма. По данным P.H. Selle с соавт. (29), у бройлеров, получавших комбикорма пшеничного типа, применение фитазы достоверно повышало использование в подвздошной кишке кальция (на 32,2 \%) и фосфора (на 28,0 \%) по сравнению с контролем. В наших опытах экзогенные фитазы способствовали более эффективной утилизации питательных веществ корма, а также кальция и фосфора. Это объясняют расщеплением фитатов (32), которые не только служат резервуаром фосфора, но и связывают значительную часть микроэлементов, а также белков, углеводов, аминокислот, превращая их в комплексные нерастворимые конгломераты. Как следствие, благодаря фитазе улучшается переваримость протеина и использование аминокислот корма, снижаются эндогенные потери аминокислот (33). Также сообщается об улучшении минерализации костяка цыплят под влиянием фитаз (34-36), что отмечалось и в наших опытах.

Таким образом, отечественные фитазы Фидбест-Р и Берзайм-Р обладают высокой ферментативной активностью, позволяющей использовать комбикорма для бройлеров с пониженным на 0,1 \% содержанием усвояемого фосфора. При этом улучшается переваримость протеина, жира, использование азота и аминокислот корма. Усвояемость кальция и фосфора 
рациона увеличивается на 3,4-7,1 \% в зависимости от дозировки препарата, лучше используются кальций, микроэлементы (железо, марганец, медь, цинк), а также протеин и аминокислоты. Под действием фитазосодержащих энзимов у бройлеров повышается минерализация костяка. Введение в рацион цыплят концентрированного препарата на основе фитазы изменяет качественный и количественный состав микробиома слепых отростков кишечника: представители нормофлоры в основном получали конкурентное преимущество, а численность условно-патогенных и патогенных форм падала.

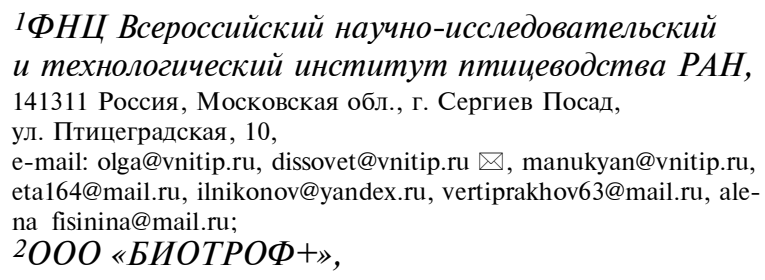
10 декабря 2018 года

192284 Россия, г. Санкт-Петербург, Загребский бульвар, 19, корп. 1,

e-mail: ilina@biotrof.ru,deniz@biotrof.ru, laptev@biotrof.ru

\title{
INTESTINAL MICROBIOTA AND BROILER PERFORMANCE UPON ADMINISTRATION OF PHYTASE TO INCREASE PHOSPHORUS DIGESTIBILITY AND NUTRIENT UTILIZATION FROM FEED
}

\author{
T.N. Lenkova', I.A. Egorov', T.A. Egorova ${ }^{1}$, V.A. Manukyan ${ }^{1}$, V.G. Vertiprakhov', \\ A.A. Grozina ${ }^{1}$, I.N. Nikonov ${ }^{1}$, V.A. Philippova ${ }^{2}$, E.A. Yildirim ${ }^{2}$, L.A. Ilina ${ }^{2}$, \\ A.V. Dubrovin'2, G.Yu Laptev²
}

\begin{abstract}
${ }^{1}$ Federal Scientific Center All-Russian Research and Technological Poultry Institute RAS, 10, ul. Ptitsegradskaya, Sergiev Posad, Moscow Province, 141311 Russia, e-mail olga@vnitip.ru, dissovet@vnitip.ru ( $\square$ corresponding author), manukyan@vnitip.ru, eta164@mail.ru, ilnikonov@yandex.ru, vertiprakhov63@mail.ru, alena_fisinina@mail.ru;

2JSC «Biotrof+», 19 korp. 1, Zagrebskii bulv., St. Petersburg, 192284 Russia, e-mail ilina@biotrof.ru, deniz@biotrof.ru, laptev@biotrof.ru

ORCID:

Lenkova T.N. orcid.org/0000-0001-8026-3983 Nikonov I.N. orcid.org/0000-0001-9495-0178

Egorov I.A. orcid.org/0000-0001-9122-9553

Egorova T.A. orcid.org/0000-0002-5102-2248

Manukyan V.A. orcid.org/0000-0003-4564-4427

Vertiprakhov V.G. orcid.org/0000-0002-3240-7636

Philippova V.A. orcid.org/0000-0001-8789-9837

Yildirim E.A. orcid.org/0000-0002-5846-5105

Ilina L.A. orcid.org/0000-0003-2490-6942

Dubrovin A.V. orcid.org/0000-0001-8424-4114

Grozina A.A. orcid.org/0000-0002-3088-0454

Laptev G.Yu. orcid.org/0000-0002-8795-6659
\end{abstract}

The authors declare no conflict of interests

Acknowledgements:

Supported financially by a grant from the Russian Science Foundation for the implementation of the scientific project 16-16-04089 "Study of the physiological and microbiological characteristics of the digestion of chicken meat in the embryonic and postembryonic periods to create new feeding technologies that ensure the fullest possible realization of the bird's genetic potential"

Received December 10, 2018

doi: 10.15389/agrobiology.2020.2.406eng

\section{Abstract}

Phosphorus is an essential element in the nutrition of humans, animals, and plants. Due to the short growth period (34-42 days of age), fast growth of live bodyweight and skeleton the problem of mineral nutrition and balance (including calcium and phosphorus) is especially urgent for broiler chicks (Gallus gallus L.). The predominant form of phosphorus in vegetable feed ingredients is phytate which is an antinutritive factor for poultry and cannot be digested. As a result the supplementation of diets for poultry with phytases, enzymes degrading the indigestible phytate complexes, has gradually become a common practice worldwide. The recent data of Russian (O.V. Trufanov, 2011; E.V. Anchikov, 2012) and foreign authors (S.W. Kim et al., 2018; C.L. Walk et al., 2019; O.O. Babatunde et al., 2019) evidenced that the supplementation of diets with reduced phosphorus content with different doses of phytase improves daily weight gains, phosphorus content in blood serum, tibial strength, and tibial contents of minerals. The efficiency of supplementation of diets for broilers (cross Cobb 500) with reduced by $0.1 \%$ phosphorus content with two innovative new-generation 
phytase preparations (Feedbest-P and Berzyme-P, produced by Sibbiopharm Co., Russia) was studied; the data of pioneer research of the effects of different phytase preparations on the cecal microbial community are also presented. The trials were performed in the Center for Genetics \& Selection Zagorskoye EPH (Moscow Province) in 2018. In the first trial the diets for experimental treatments were supplemented with phytase preparation 1 with activity 10,000 FTU/g (20, 40, and $60 \mathrm{ppm})$; in the second trial phytase preparation 2 was used with activity 50,000 FTU/g (6, 12, and $30 \mathrm{ppm})$. The supplementation of diets with preparation 1 increased live bodyweight in broilers at 37 days of age by 2.7; 3.0 and $3.7 \%$ (respective to aforementioned doses) in compare to non-supplemented control treatment; feed conversion ratio (FCR) in these treatments was better by $2.9 ; 4.0$ and $4.6 \%$, respectively. The respective improvements with different doses of preparation 2 were $1.3 ; 3.1$ and $2.0 \%$ and $1.9 ; 5.6$ and $3.7 \%$. Positive effects on the digestibility of dietary nutrients, deposition of calcium and phosphorus, mineral contents in the skeleton were found with both phytase preparations. The investigation of cecal microbiota using T-RFLP (terminal restriction fragment length polymorphism) method revealed the significant increase in the pool of cellulolytic bacterial species in the phytase-fed broilers; the increases in the species of Eubacteriaceae, Clostridiaceae, Lachnospiraceae, Ruminococcaceae, and Bacteroidetes were also found. The most of the identified bacterial species in cecal population were ascribed to the phylums Firmicutes, Bacteroidetes, Actinobacteria, Proteobacteria and Fusobacteria.

Keywords: Gallus gallus, phytase, compound feeds, broiler chicks, productive performance, cecal microbiota.

\section{REFEREN CES}

1. Trufanov O.V. Fitaza v kormlenii sel'skokhozyaistvennykh zhivotnykh [Phytase in feeding farm animals]. Kiev, 2011 (in Russ.).

2. Ravindran V. Phytases in poultry nutrition. An overview. Proceedings of Australian Poultry Science Symposium, 1995, 7: 135-139.

3. Singh P.K. Significance of phytic acid and supplemental phytase in chicken nutrition: a review. World's Poultry Science Journal, 2008, 64(4): 553-580 (doi: 10.1017/S0043933908000202).

4. Anchikov E.V. Fitaza $v$ kombikormakh dlya broilerov. Avtoreferat kandidatskoi dissertatsii [Phytase in feed for broilers. PhD Thesis]. Sergiev Posad, 2012 (in Russ.).

5. Selle P., Anchikov E. Kombikorma, 2010, 3: 81-85 (in Russ.).

6. Uord N., Glitso V. Kombikorma, 2014, 1: 78 (in Russ.).

7. Shirley R.B., Edwards H.M. Jr. Graded levels of phytase past industry standards improves broiler performance. Poultry Science, 2003, 82(4): 671-680 (doi: 10.1093/ps/82.4.671).

8. Walk C.L., Rama Rao S.V. Increasing dietary phytate has a significant anti-nutrient effect on apparent ileal amino acid digestibility and digestible amino acid intake requiring increasing doses of phytase as evidenced by prediction equations in broilers. Poultry Science, 2020, 99(1): 290300 (doi: 10.3382/ps/pez489).

9. Babatunde O.O., Cowieson A.J., Wilson J.W., Adeola O. The impact of age and feeding length on phytase efficacy during the starter phase of broiler chickens. Poultry Science, 2019, 98(12): 6742-6750 (doi: 10.3382/ps/pez390).

10. Kim S.W., Li W., Angel R., Proszkowiec-Weglarz M. Effects of limestone particle size and dietary $\mathrm{Ca}$ concentration on apparent $\mathrm{P}$ and $\mathrm{Ca}$ digestibility in the presence or absence of phytase. Poultry Science, 2018, 97(12): 4306-4314 (doi: 10.3382/ps/pey304).

11. Roofchaei A., Rezaeipour V., Vatandour S., Zaefarian F. Influence of dietary carbohydrases, individually or in combination with phytase or an acidifier, on performance, gut morphology and microbial population in broiler chickens fed a wheat-based diet. Animal Nutrition, 2019, 5(1): 63-67. (doi: 10.1016/j.aninu.2017.12.001).

12. Apajalahti J., Kettunen A., Graham H. Characteristics of the gastrointestinal microbial communities, with special reference to the chicken. World's Poultry Science Journal, 2004, 60(2): $223-$ 232 (doi: 10.1079/WPS200415).

13. Amit-Romach E., Sklan D., Uni Z. Microflora ecology of the chicken intestine using 16S ribosomal DNA primers. Poultry Science, 2004, 83(7): 1093-1098 (doi: 10.1093/ps/83.7.1093).

14. Lan Y., Verstegen M.W.A., Tamminga S., Williams B.A. The role of the commensal gut microbial community in broiler chickens. World's Poultry Science Journal, 2005, 61(1): 95-104 (doi: 10.1079/WPS200445).

15. Adegunloye D.V. Microorganism associated with poultry faeces. Journal of Food, Agriculture and Environment, 2006, 4: 41-42.

16. Wei S., Morrison M., Yu Z. Bacterial census of poultry intestinal microbiome. Poultry Science, 2013, 92(3): 671-683 (doi: 10.3382/ps.2012-02822).

17. Lukashenko V.S., Kavtarashvili A.Sh., Saleeva I.P. et al. Metodika provedeniya issledovanii po tekhnologii proizvodstva yaits $i$ myasa ptitsy [Egg and poultry production technology - method- 
ology for research]. Sergiev Posad, 2008 (in Russ.).

18. Egorov I.A., Manukyan V.A., Lenkova T.N., Okolelova T.M., Lukashenko V.S., Shevyakov A.N., Ignatova G.V., Egorova T.V., Andrianova E.N., Rozanov B.L., Lysenko M.A., Egorova T.A., Grozina A.A., Laptev G.Yu., Nikonov I.N., Aleksandrova I.L., Il'ina L.A., Novikova N.I. Metodika provedeniya nauchnykh i proizvodstvennykh issledovanii po kormleniyu sel'skokhozyaistvennoi ptitsy. Molekulyarno-geneticheskie metody opredeleniya mikroflory kishechni$\mathrm{ka}$ /Pod redaktsiei V.I. Fisinina, I.A. Egorova [Methods of scientific and farm tests on feeding poultry. Molecular genetic methods for the determination of intestinal microflora. V.I. Fisinin, I.A. Egorov (eds.)]. Sergiev Posad, 2013 (in Russ.).

19. Uilson K., Uolker Dzh. Printsipy $i$ metody biokhimii $i$ molekulyarnoi biologii [Principles and methods of biochemistry and molecular biology]. Moscow, 2013 (in Russ.).

20. Lakin G.F. Biometriya [Biometrics]. Moscow, 1990 (in Russ.).

21. Borda-Molina D., Seifert J., Camarinha-Silva A. Current perspectives of the chicken gastrointestinal tract and its microbiome. Computational and Structural Biotechnology Journal, 2018, 16: 131-139 (doi: 10.1016/j.csbj.2018.03.002).

22. Lu J., Idris U., Harmon B., Hofacre C., Maurer J.J., Lee M.D. Diversity and succession of the intestinal bacterial community of the maturing broiler chicken. Applied and Environmental Microbiology, 2003, 69(11): 6816-6824 (doi: 10.1128/AEM.69.11.6816-6824.2003).

23. Józefiak D., Rutkowski A., Kaczmarek S., Jensen B.B., Engberg R.M., Hojberg O. Effect of $\beta$ glucanase and xylanase supplementation of barley- and rye-based diets on caecal microbiota of broiler chickens. British Poultry Science, 2010, 51(4): 546-557 (doi: 10.1080/00071668.2010.507243).

24. Singh K.M., Shah T., Deshpande S., Jakhesara S.J., Koringa P.G., Rank D.N., Joshi C.G. High through put $16 \mathrm{~S}$ rRNA gene-based pyrosequencing analysis of the fecal microbiota of high FCR and low FCR broiler growers. Mol. Biol. Rep., 2012, 39: 10595-10602 (doi: 10.1007/s11033-012-1947-7).

25. Ptak A., Bedford M.R., Świątkiewicz S., żyła K., Józefiak D. Phytase modulates ileal microbiota and enhances growth performance of the broiler chickens. PLOS ONE, 2015, 10(3): e0119770 (doi: 10.1371/journal.pone.0119770).

26. Peterson E. H. Clostridium novyi isolated from chickens. Poultry Science, 1964, 43(4): 10621063. (doi: 10.3382/ps.0431062).

27. Cooper K.K., Theoret J.R., Stewart B.A., Trinh H.T., Glock R.D., Songer J.G. Virulence for chickens of Clostridium perfringens isolated from poultry and other sources. Anaerobe, 2010, 16(3): 289-292 (doi: 10.1016/j.anaerobe.2010.02.006).

28. Abd-Elsamee M.O. Effect of different levels of crude protein, sulphur amino acids, microbial phytase and their interaction on broiler chick performance. Egypt. Poult. Sci., 2002, 22: 999-1021.

29. Selle P.H., Ravindran V., Partridge G.G. Beneficial effects of xylanase and/or phytase inclusions on ileal amino acid digestibility, energy utilisation, mineral retention and growth performance in wheat-based broiler diets. Animal Feed Science and Technology, 2009, 153(3-4): 303313 (doi: 10.1016/j.anifeedsci.2009.06.011).

30. Deniz G., Gezen S.S., Kara C., Gencoglu H., Meral Y., Baser E. Evaluation of nutrient equivalency of microbial phytase in hens in late lay given maize-soybean or distiller's dried grains with solubles (DDGS) diets. British Poultry Science, 2013, 54(4): 494-502 (doi: 10.1080/00071668.2013.797954).

31. Liu N., Ru Y.J. Effect of phytate and phytase on the ileal flows of endogenous minerals and amino acids for growing broiler chickens fed purified diets. Animal Feed Science and Technology, 2010, 156(3-4): 126-130 (doi: 10.1016/j.anifeedsci.2010.01.008).

32. Cowieson A., Ravindran V. Effect of phytic acid and microbial phytase on the flow and amino acid composition of endogenous protein at the terminal ileum of growing broiler chickens. British Journal of Nutrition, 2007, 98(4): 745-752 (doi: 10.1017/S0007114507750894).

33. Englmaierová M., Skřivan M., Skřivanová E., Čermák L. Limestone particle size and Aspergillus niger phytase in the diet of older hens. Italian Journal of Animal Science, 2017: 608-615 (doi: 10.1080/1828051X.2017.1309258).

34. de Sousa J.P.L., Albino L.F.T., Vaz R.G.M.V., Rodrigues K.F., da Silva G.F., Renno L.N., Barros V.R.S.M., Kaneko I.N. The effect of dietary phytase on broiler performance and digestive, bone, and blood biochemistry characteristics. Rev. Bras. Cienc. Avic., 2015, 17(1): 69-76 (doi: 10.1590/1516-635x170169-76).

35. Abbasi M., Zaghari M., Ganjkhanlo M., Khalaji S. Is dietary iron requirement of broiler breeder hens at the late stage of production cycle influenced by phytase supplementation? Journal of Applied Animal Research, 2015, 43(2): 166-176 (doi: 10.1080/09712119.2014.928634). 